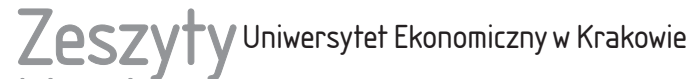 Naukowe
}

\section{Analiza poziomu infrastruktury sportowej w ujęciu lokalnym i regionalnym}

\section{Streszczenie}

Celem artykułu było przedstawienie metody pozwalającej na analizę porównawczą poziomu infrastruktury sportowej w przekroju jednostek samorządu terytorialnego (województwa Polski, gminy powiatu wadowickiego). Znając stosunek liczby obiektów sportowych do liczby mieszkańców, można próbować ustalić korzystne rozwiązanie w zakresie polityki rozwoju lokalnej infrastruktury sportowej. Ze względu na dostępność danych analiza możliwa było tylko za lata 2010 i 2014. Do tego celu wykorzystano informacje dotyczące obiektów sportowych udostępnione przez Wojewódzki Urząd Statystyczny w Krakowie. Zbadano liczbę mieszkańców przypadającą na jeden obiekt sportowy we wszystkich jednostkach terytorialnych.

Słowa kluczowe: infrastruktura, sport, powiat, województwo małopolskie.

Klasyfikacja JEL: H41, I10, R58.

\section{Wprowadzenie}

Dostępność obiektów sportowych związana jest z wieloma zagadnieniami. Można mówić o aktualności tej problematyki w kontekście rozwoju regionalnego i lokalnego. Ponadto istotnym tematem jest promocja wszelkiej aktywności fizycznej, która ma wpływ na stan zdrowia społeczeństwa. UNICEF (Warunki... 
2013, s. 49) informuje, że odsetek dzieci z nadwagą wzrósł w ciągu dekady (tj. w latach 2001-2010) w 17 z 21 badanych krajów. Najwyższy wzrost zaobserwowano w Polsce, gdzie procent dzieci z nadwagą podwoił się. Jedynie Belgia, Francja, Hiszpania i Wielka Brytania odnotowały zmniejszenie się odsetka dzieci z nadwagą. Stany Zjednoczone miały najwyższy odsetek dzieci z nadwagą zarówno na początku, jak i na końcu dekady, wynoszący niemal 30\% w latach 2009-2010 (Warunki... 2013, s. 49). Nadwagę ma 17\% dzieci w wieku 11, 13 i 15 lat. Ok. 80\% otyłych nastolatków pozostanie otyłymi w wieku dorosłym (Sport... 2016). Istotną kwestią są wszelkiego rodzaju zajęcia dodatkowe, które mają wzbogacić obowiązkową edukację fizyczną. Kraje europejskie stosują różne programy w tym zakresie. Każdy z nich potwierdza, że władze publiczne zdają sobie sprawę z istotności i konieczności zwiększenia aktywności fizycznej wśród dzieci i młodzieży (Physical Education... 2013, s. 41-43).

Do uprawiania sportu potrzeba odpowiednich warunków, a w szczególności infrastruktury sportowej. Temat inwestycji w tym zakresie to niezwykle istotne i stale aktualne zagadnienie niezależnie od szczebla jednostki samorządu terytorialnego. Podjęcie go wiąże się jednak z koniecznością odpowiedzi na pytania o różnym charakterze. Dotyczą one choćby wyboru priorytetowych inwestycji spośród wielu innych, które poszczególne jednostki samorządu terytorialnego muszą wykonać. Osobnym tematem jest finansowanie. Chodzi nie tylko o budowę obiektów, ale również w późniejszym okresie ich utrzymanie, pozyskiwanie środków na potrzebne remonty. Nie ma jednolitego schematu kształtowania polityki inwestycyjnej. W każdym samorządzie panują inne warunki społeczno-ekonomiczne, do których należy dostosować zamierzenia inwestycyjne. Faktem jest jednak, że JST może na drodze uchwały wskazać warunki i tryb finansowania zadania, zaznaczając cel publiczny z zakresu sportu, także związany z korzystaniem z infrastruktury sportowej, który zamierza osiągnąć (Rzeszowski 2017, s. 49 i nast.).

Badania przeprowadzone przez A. Hadzika i M. Grabarę (2014, s. 97 i 100) wskazują, że infrastruktura sportowa i rekreacyjna jest również istotna w rozwoju gmin uzdrowiskowych. Autorzy przeprowadzili ankietę, w której gminy objęte badaniem zadeklarowały inwestycje w infrastrukturę rekreacyjną i sportową, najczęściej boiska piłkarskie, ale też trasy rowerowe. Połączenie turystyki sportowej z turystyką uzdrowiskową oraz stosowanie w tym zakresie innowacyjnych rozwiązań może się okazać konieczne, aby sprostać oczekiwaniom coraz bardziej wymagających użytkowników i konkurencji ze strony zagranicznych ośrodków leczniczych.

Celem artykułu jest przedstawienie metody, dzięki której jednostki samorządu terytorialnego mogą ocenić poziom infrastruktury sportowej na swoim terenie na tle innych JST. Znając liczbę obiektów, które powinny się pojawić, można 
próbować wypracować korzystne rozwiązanie w zakresie polityki rozwoju lokalnej infrastruktury sportowej. Należy jednak zaznaczyć, że nie ma jednego, idealnego modelu rozwoju infrastruktury sportowej. Nie można stwierdzić, że im więcej obiektów sportowych, tym lepiej. W analizie wykorzystano informacje o liczbie obiektów sportowych, a nie o ich wartości. Liczba obiektów sportowych ma ograniczoną porównywalność pod względem wielkości, przeznaczenia i funkcjonalności. Niestety nie dysponowano wyceną poszczególnych obiektów sportowych, co pozwalałoby na bardziej adekwatną analizę porównawczą w zakresie rozwoju infrastruktury sportowej. Brak informacji na temat wartości obiektów, kosztów ich utrzymania itd. sprawia, że przeprowadzone rozważania mają charakter wstępny i jako takie stanowią jedną z przesłanek dla władz JST do podejmowania odpowiednich decyzji i działań.

\section{Pojęcie infrastruktury sportowej i jej uwarunkowania}

Słowo „sport” wywodzi się z łacińskiego słowa se desportatre i oznacza oddawanie się rozrywkom, bawienie się lub przyjemne spędzanie czasu (Babczuk i Łebek 2013, s. 7). W zabawie i przyjemnym spędzaniu czasu istotna wydaje się odpowiednio przygotowana infrastruktura sportowa.

W ustawie z dnia 25 czerwca 2010 r. o sporcie czytamy, że kulturę fizyczną tworzy sport razem z wychowaniem fizycznym i rehabilitacją ruchową. Sam sport określa się jako każdą aktywność fizyczną, która przez chwilowe czy systematyczne uczestnictwo wpływa na stworzenie lub polepszenie formy fizycznej i psychicznej, rozwój stosunków społecznych lub uzyskanie wyników sportowych na wszystkich poziomach.

Infrastruktura jest podstawą działalności gospodarczej, ale jest również istotna dla codziennego funkcjonowania mieszkańców danego obszaru. Zwykle mówi się o dwóch jej rodzajach, tj. społecznej i technicznej, wskazuje się jednak także tzw. infrastrukturę instytucjonalną (Ossowska 2005, s. 331).

K. Krzyżanowska (2005, s. 207) zaznacza, że obiekty sportowe wraz z obiektami wypoczynkowymi, biurami turystycznymi, informacją turystyczną itp. składają się na infrastrukturę społeczną. Rozpatrując problematykę poziomu infrastruktury sportowej, można ją zatem sklasyfikować jako część infrastruktury społecznej i włączyć w ogólny program rozwoju lokalnej infrastruktury społecznej. Zdaniem K. Krzyżanowskiej urządzenia sportowo-rekreacyjne umożliwiające czynny wypoczynek w czasie pobytu turystycznego są jednym z elementów służących do oceny infrastruktury turystycznej.

M. Ratajczak (1999, s. 33) zwraca uwagę, że infrastruktura stanowi kombinację wysokiego ryzyka inwestycyjnego, ogólnogospodarczych i ogólnospołecznych 
efektów (tj. zagwarantowania wszystkim zainteresowanym w miarę równego dostępu do usług infrastruktury) oraz ograniczonych możliwości, a czasem ich braku, oparcia funkcjonowania infrastruktury na regułach rynkowych.

Poziom lokalnej infrastruktury jest skorelowany z rozwojem lokalnym, na który zaczęto zwracać uwagę po reformie samorządowej w latach 90 . XX w. Na skutek wspomnianej reformy określona została, jak pisze M. Dolata (2010, s. 44), szczególna pozycja samorządu lokalnego w państwie. Jednostki samorządu terytorialnego wraz z osobowością prawną uzyskały prawo do majątku i dochodów, ale zobowiązano je również do samodzielnego decydowania o ich dysponowaniu w zakresie realizowanych inwestycji oraz kreowania warunków służących rozwojowi lokalnemu. Podejmowane inwestycje mają na celu realizację zadań publicznych (własnych lub zleconych), a te mają zaspokoić zbiorowe potrzeby mieszkańców (Satoła 2013, s. 185).

Aby precyzyjniej określić obszar działalności związanej ze sportem, niezbędne wydaje się odwołanie do Rozporządzenia Rady Ministrów z dnia 24 grudnia 2007 r. w sprawie Polskiej Klasyfikacji Działalności (2007), w którym dokonano podziału działalności podmiotów wpisanych do krajowego rejestru urzędowego podmiotów gospodarki narodowej (REGON) na sekcje (A-U), działy (1-99), grupy i podklasy.

Działalność sportowa została sklasyfikowana w sekcji $\mathrm{R}$, tj. jako działalność związana z kulturą, rozrywką i rekreacją. Sekcja ta obejmuje działalność kulturalną, rozrywkową i rekreacyjną związaną z różnymi zainteresowaniami społeczeństwa, włączając występy na żywo, działalność muzeów, gry hazardowe, działalność związaną ze sportem i rekreacją. Dział 93 sekcji R (tj. działalność sportowa, rozrywkowa i rekreacyjna) obejmuje grupę 93.1 (tj. działalność związaną ze sportem), w której oprócz prowadzenia obiektów sportowych znalazły się również:

- działalność drużyn i klubów sportowych oraz niezależnych sportowców biorących udział głównie w imprezach sportowych na żywo przed publicznością,

- działalność właścicieli samochodów wyścigowych, psów, koni itd. biorących udział w wyścigach, polegająca przede wszystkim na wystawianiu ich na wyścigach lub innych imprezach sportowych,

- działalność trenerów sportowych świadczących specjalistyczne usługi dla uczestników imprez i zawodów sportowych, działalność związana z prowadzeniem hal sportowych i stadionów,

- pozostała działalność w zakresie organizowania, promowania i zarządzania imprezami sportowymi, gdzie indziej niesklasyfikowana.

Wspomniana działalność obiektów sportowych obejmuje:

1) działalność obiektów sportowych na otwartym powietrzu lub obiektów sportowych halowych (otwartych, zamkniętych lub zadaszonych, z miejscami siedzącymi dla widzów lub bez), tj.: 
- stadiony do gry w piłkę nożną,

- stadiony do gry w krykieta, rugby,

- tory wyścigowe dla samochodów, psów, koni,

- baseny,

- stadiony lekkoatletyczne,

- hale i stadiony przeznaczone dla sportów zimowych, włączając hale do gry w hokeja,

- hale bokserskie,

- pola golfowe,

- tory do gry w kręgle,

- pozostałe obiekty sportowe;

2) organizowanie i przeprowadzanie imprez sportowych dla sportowców zawodowych lub amatorów z wykorzystaniem własnych, otwartych lub zamkniętych obiektów sportowych,

3) zarządzanie i zapewnienie pracowników do obsługi tych obiektów.

Podklasa 93.13.Z (tj. działalność obiektów służących poprawie kondycji fizycznej) obejmuje: działalność centrów i klubów fitness oraz innych obiektów służących poprawie kondycji fizycznej i kulturystyce (http://www.klasyfikacje. gofin.pl/pkd/5,2,1505,dzialalnosc-sportowa-rozrywkowa-i-rekreacyjna.html, data dostępu: 13.08.2017). Skorzystanie z informacji zawartych w Polskiej Klasyfikacji Działalności pozwala na zobrazowanie skali różnego rodzaju tematów związanych z rozwojem lokalnej infrastruktury sportowej. Chodzi nie tylko o budowę i utrzymanie obiektów, ale również o wiele innych działań z nimi związanych, np. przeprowadzanie imprez czy zatrudnianie pracowników.

By poprawnie funkcjonować, gmina powinna stworzyć plan swojego rozwoju. Taką wizją rozwoju gminy jest strategia rozwoju lub lokalny plan rozwoju. Określa on docelową wizję rozwoju, misję gminy, (strategiczne) cele rozwoju, zadania (strategiczne) oraz sposób ich realizacji. Podmiotem tej wizji jest społeczność lokalna uczestnicząca w realizacji zadań strategicznych. Jest ona także odbiorcą powstających w efekcie zastosowania wizji rozwoju zmian, nowych warunków prowadzenia działalności gospodarczej i poprawy jakości życia. Przedmiot rozwoju lokalnego stanowi gminna rzeczywistość w wymiarach: przestrzennym, gospodarczym, społecznym i ekologicznym (Zarzqdzanie... 1998, s. 17).

Gmina jako jednostka samorządu terytorialnego wykonuje zadania własne w swoim imieniu i na własną odpowiedzialność (Konstytucja Rzeczypospolitej Polskiej z dnia 2 kwietnia 1997 r. ...). Nie może odmówić ich wykonania, jeżeli tak stanowi ustawa. Ustawodawca celowo wprowadził zadania obowiązkowe, by zabezpieczyć mieszkańcom określony poziom zaspokojenia potrzeb. To także gwarancja prawna równości wobec prawa i dążenie do takiego samego dostępu do świadczeń niezależnie od miejsca zamieszkania. Gmina jako jednostka samo- 
rządu terytorialnego podlega kontroli z punktu widzenia legalności. Mówi o tym art. 171 Konstytucji RP. Działalność gminy nadzoruje prezes Rady Ministrów, a jej finanse kontroluje regionalna izba rozrachunkowa.

$\mathrm{W}$ ramach analizy podjęto temat związany $\mathrm{z}$ ustaleniem pożądanego poziomu infrastruktury sportowej, wykorzystując wskaźniki obłożenia obiektów sportowych w przekroju gmin i województw.

Należy podkreślić, że w analizie wykorzystano informacje o liczbie obiektów sportowych, a nie o ich wartości. Liczba obiektów sportowych ma ograniczoną porównywalność pod względem wielkości, przeznaczenia i funkcjonalności. Niestety nie dysponowano wyceną poszczególnych obiektów sportowych, co pozwalałoby na formułowanie porównywalnych w przekroju gmin wniosków dla całości infrastruktury sportowej. Analiza ma charakter przybliżony i jest oparta na wskaźniku demograficznym, a powinna wykorzystywać również elementy kosztowe.

\section{Analiza regionalnej infrastruktury sportowej na podstawie danych GUS}

W analizie wykorzystano dane statystyczne za lata 2010 i 2014, dostępne w Wojewódzkim Urzędzie Statystycznym w Krakowie. Na podstawie zebranych informacji wyznaczono wskaźniki liczby mieszkańców przypadających na jeden obiekt sportowy. Pozwoliło to na zróżnicowanie badanych JST pod względem dostępności obiektów sportowych. Ponadto zdefiniowano tzw. demograficzną liczbę obiektów, będącą liczbą obiektów sportowych proporcjonalną do liczby ludności danej jednostki terytorialnej. Wskaźnik ten porównywano ze wskaźnikami dla całej Polski. Można byłoby rozważyć wyznaczanie optymalnych wskaźników w relacji do wskaźników najbardziej korzystnych, przy czym należy zwrócić uwagę na możliwe wysokie zróżnicowanie wyników wynikające z nietypowej wartości wskaźnika najkorzystniejszego. Lepszym rozwiązaniem może być uwzględnienie wskaźnika nie najkorzystniejszego, ale wyznaczonego na poziomie np. pierwszego kwartyla dzielącego zbiorowość jednostek terytorialnych na dwie części: poniżej jest 25\% JST, a powyżej 75\% JST. W analizie wykorzystano pierwsze z wymienionych podejść.

Analizę regionalnej infrastruktury sportowej przeprowadzono na poziomie województw, korzystając z danych za 2014 r., na podstawie których wyznaczono dla każdego województwa następujące parametry (tabela 1):

- liczba ludności (L) oraz liczba obiektów sportowych (O),

- liczba mieszkańców przypadająca na jeden obiekt sportowy (L/O),

- udział liczby ludności danego województwa w liczbie ludności ogółem w Polsce (\% L), 
- udział liczby obiektów sportowych w ogólnej liczbie obiektów w Polsce dla poszczególnych województw (\% O),

- relacja wskaźnika obłożenia obiektów sportowych do tego wskaźnika dla całego kraju (\% L/O),

- teoretyczna (demograficzna) liczba obiektów w poszczególnych województwach $(\mathrm{O} 2)$ wyznaczona na poziomie wskaźnika dla całego kraju,

- różnice pomiędzy teoretyczną a faktyczną liczbą obiektów (O2-O) wskazujące na wielkość dysproporcji pomiędzy tymi parametrami.

Na podstawie wartości zaprezentowanych w tabeli 1 obliczono wskaźnik obłożenia L/O oraz wielkość infrastruktury sportowej w poszczególnych województwach przy założeniu, że wszystkie mają wskaźnik identyczny jak wartość tego wskaźnika dla Polski.

W tabeli 1 ułożono województwa w kolejności od mającego największą liczbę osób przypadających na obiekt sportowy do mającego liczbę najmniejszą. Idealne wydawać by się mogło województwo opolskie, gdyż ma najniższy wynik L/O, tj. 982. Na kwestię liczby mieszkańców przypadających na jeden obiekt sportowy można patrzeć z kilku perspektyw: sportowej, finansowej i in., dlatego też nie można jednoznacznie stwierdzić, że województwo opolskie jest najlepsze. Biorąc jednak pod uwagę dostępność obiektów, można zauważyć, że we wspomnianym województwie mieszkańcy mają lepszy dostęp do infrastruktury sportowej niż w innych. W Polsce ogółem na jeden obiekt sportowy w kraju przypada 1711 osób. Najtrudniejsza sytuacja z dostępem do infrastruktury sportowej jest w województwie mazowieckim (2873 osoby na obiekt sportowy). Wskaźniki najbardziej zbliżone do wartości dla całego kraju mają województwa kujawsko-pomorskie (1726 osób na obiekt) i pomorskie (1644 osoby na obiekt).

Z informacji przedstawionych w kolumnach 5 i 6 wynika, że województwa posiadające największy udział liczby mieszkańców w liczbie ludności Polski ogółem (\% L), tj. mazowieckie (14\%) i śląskie (12\%), nie mają równie wysokiego udziału w liczbie obiektów sportowych, gdyż jest to odpowiednio $8 \%$ oraz $9 \%$. Największa rozbieżność w tym zakresie występuje w województwie mazowieckim (6\%). Województwa o najniższym udziale ludności, tj. świętokrzyskie, podlaskie i lubuskie (po 3\% każde), mają także najniższy udział obiektów sportowych.

Na województwa opolskie, podkarpackie, zachodniopomorskie, lubuskie, dolnośląskie czy wielkopolskie spojrzeć należy przez pryzmat relacji wskaźnika obłożenia obiektów sportowych do tego wskaźnika dla całego kraju (\% L/O). We wspomnianych JST stosunek ten jest najniższy. Najwyższy jest natomiast w województwach mazowieckim (168\%) i podlaskim (146\%); władze tych JST powinny zastanowić się nad zwiększeniem liczby obiektów sportowych. 
Tabela 1. Liczba mieszkańców przypadających na jeden obiekt sportowy według województw (stan na 31 grudnia 2014 r.)

\begin{tabular}{|c|c|c|c|c|c|c|c|c|}
\hline Województwo & $\mathrm{L}$ & $\mathrm{O}$ & $\mathrm{L} / \mathrm{O}$ & $\% \mathrm{~L}$ & $\% \mathrm{O}$ & $\mathrm{O} 2$ & $\mathrm{O} 2-\mathrm{O}$ & $\% \mathrm{~L} / \mathrm{O}$ \\
\hline \multicolumn{9}{|c|}{ Według malejącej liczby mieszkańców } \\
\hline Mazowieckie & 5334511 & 1857 & 2873 & 14 & 8 & 3118 & 1261 & 168 \\
\hline Śląskie & 4585924 & 2008 & 2284 & 12 & 9 & 2681 & 673 & 133 \\
\hline Wielkopolskie & 3472579 & 2583 & 1344 & 9 & 11 & 2030 & -553 & 79 \\
\hline Małopolskie & 3368336 & 2157 & 1562 & 9 & 10 & 1969 & -188 & 91 \\
\hline Dolnośląskie & 2908457 & 2173 & 1338 & 8 & 10 & 1700 & -473 & 78 \\
\hline Łódzkie & 2504136 & 1188 & 2108 & 7 & 5 & 1464 & 276 & 123 \\
\hline Pomorskie & 2302077 & 1400 & 1644 & 6 & 6 & 1346 & -54 & 96 \\
\hline Lubelskie & 2147746 & 988 & 2174 & 6 & 4 & 1255 & 267 & 127 \\
\hline Podkarpackie & 2129187 & 1946 & 1094 & 6 & 9 & 1245 & -701 & 64 \\
\hline Kujawsko-pomorskie & 2089992 & 1211 & 1726 & 5 & 5 & 1222 & 11 & 101 \\
\hline Zachodniopomorskie & 1715431 & 1336 & 1284 & 4 & 6 & 1003 & -333 & 75 \\
\hline Warmińsko-mazurskie & 1443967 & 907 & 1592 & 4 & 4 & 844 & -63 & 93 \\
\hline Świętokrzyskie & 1263176 & 576 & 2193 & 3 & 3 & 738 & 162 & 128 \\
\hline Podlaskie & 1191918 & 477 & 2499 & 3 & 2 & 697 & 220 & 146 \\
\hline Lubuskie & 1020307 & 787 & 1296 & 3 & 3 & 596 & -191 & 76 \\
\hline Opolskie & 1000858 & 1019 & 982 & 3 & 5 & 585 & -434 & 57 \\
\hline Polska & 38478602 & 22491 & 1711 & 100 & 100 & 22491 & 0 & 100 \\
\hline \multicolumn{9}{|c|}{ Według malejącego wskaźnika L/O } \\
\hline Mazowieckie & 5334511 & 1857 & 2873 & 14 & 8 & 3118 & 1261 & 168 \\
\hline Podlaskie & 1191918 & 477 & 2499 & 3 & 2 & 697 & 220 & 146 \\
\hline Śląskie & 4585924 & 2008 & 2284 & 12 & 9 & 2681 & 673 & 133 \\
\hline Świętokrzyskie & 1263176 & 576 & 2193 & 3 & 3 & 738 & 162 & 128 \\
\hline Lubelskie & 2147746 & 988 & 2174 & 6 & 4 & 1255 & 267 & 127 \\
\hline Łódzkie & 2504136 & 1188 & 2108 & 7 & 5 & 1464 & 276 & 123 \\
\hline Kujawsko-pomorskie & 2089992 & 1211 & 1726 & 5 & 5 & 1222 & 11 & 101 \\
\hline Pomorskie & 2302077 & 1400 & 1644 & 6 & 6 & 1346 & -54 & 96 \\
\hline Warmińsko-mazurskie & 1443967 & 907 & 1592 & 4 & 4 & 844 & -63 & 93 \\
\hline Małopolskie & 3368336 & 2157 & 1562 & 9 & 10 & 1969 & -188 & 91 \\
\hline Wielkopolskie & 3472579 & 2583 & 1344 & 9 & 11 & 2030 & -553 & 79 \\
\hline Dolnośląskie & 2908457 & 2173 & 1338 & 8 & 10 & 1700 & -473 & 78 \\
\hline Lubuskie & 1020307 & 787 & 1296 & 3 & 3 & 596 & -191 & 76 \\
\hline Zachodniopomorskie & 1715431 & 1336 & 1284 & 4 & 6 & 1003 & -333 & 75 \\
\hline Podkarpackie & 2129187 & 1946 & 1094 & 6 & 9 & 1245 & -701 & 64 \\
\hline Opolskie & 1000858 & 1019 & 982 & 3 & 5 & 585 & -434 & 57 \\
\hline Polska & 38478602 & 22491 & 1711 & 100 & 100 & 22491 & 0 & 100 \\
\hline
\end{tabular}

Źródło: opracowanie własne na podstawie danych GUS. 
Analizując liczbę obiektów według średniej, tj. danych dla Polski ogółem, można zauważyć, że w przypadku województwa mazowieckiego różnica wynosi 1261 obiektów, co stanowi $68 \%$ podstawowego stanu infrastruktury sportowej.

Dane ósmej i dziewiątej kolumny tabeli 1 pozwalają zauważyć, że w województwach śląskim oraz mazowieckim powinno pojawić się więcej obiektów sportowych. Wynika to z faktu, że udział mieszkańców wspomnianych województw w populacji ogółem w Polsce jest wyższy niż odpowiadający mu udział obiektów sportowych. Sytuacją idealną z punktu widzenia rozwoju infrastruktury sportowej byłaby taka, w której te udziały byłyby równe lub porównywalne, jak np. w województwach warmińsko-mazurskim (po 4\%), pomorskim (po 6\%) czy kujawsko-pomorskim (po 5\%).

Należy podkreślić, że powyższe obliczenia mają charakter przybliżony. Można się zastanowić: czy jest możliwe, by w całej Polsce był taki sam dostęp do obiektów sportowych? czy realne jest, by poszczególne jednostki samorządu terytorialnego miały taki sam poziom infrastruktury sportowej? czy jest możliwa likwidacja podziału Polski na tereny z dobrą i z gorszą dostępnością do obiektów sportowych. co należy zrobić, by poszczególne województwa miały taki sam poziom infrastruktury jak województwo opolskie czy odpowiadający średniej krajowej. Stanu równości nie osiągnie się nigdy, gdyż każdy region jest inny, ma inną specyfikę, priorytety itd.

\section{Analiza porównawcza lokalnej infrastruktury sportowej}

By określić odpowiedni poziom lokalnej infrastruktury sportowej, należy zapoznać się z jej stanem na badanym terenie. Do tego celu wykorzystano dane pochodzące z Działu Udostępniania Informacji w Urzędzie Statystycznym w Krakowie dotyczące obiektów sportowych. Informacje te zebrane zostały na podstawie sprawozdań KFT-OB/a i KFT-OB/b. Badania przeprowadzono w latach 2010 i 2014 i nie obejmują one obiektów przyszkolnych. Dostępne dane odnoszą się do gmin.

W analizie wykorzystano następujące wskaźniki:

- obłożenie obiektów sportowych liczbą mieszkańców w danej gminie wyrażone jako L/O, gdzie L oznacza liczbę ludności, a $\mathrm{O}$ - liczbę obiektów sportowych,

- relację wskaźnika obłożenia obiektów sportowych do tego wskaźnika dla całego powiatu $(\% \mathrm{~L} / \mathrm{O})$,

- udział liczby ludności danej gminy w liczbie ludności powiatu ogółem (\% L),

- udział liczby obiektów sportowych w ogólnej liczbie obiektów w powiecie dla poszczególnych gmin (\% O),

- teoretyczną (demograficzną) liczbę obiektów w poszczególnych gminach (O2) wyznaczoną na poziomie wskaźnika dla całego powiatu, 
- różnice pomiędzy teoretyczną a faktyczną liczbą obiektów (O2-O) wskazujące na wielkość dysproporcji pomiędzy tymi parametrami.

W tabeli 2 zaprezentowano powyższe parametry uporządkowane najpierw w kolejności według malejącej liczby mieszkańców, malejącego wskaźnika L/O (relacja wskaźnika obłożenia obiektów sportowych danej gminy do wskaźnika dla powiatu), a później według optymalnego rozwiązania. Wyliczenia w niej zawarte wskazują, że na jeden obiekt w powiecie przypada 1608 osób (mniej niż średnia krajowa, co wyliczono powyżej). Najlepiej sytuacja pod tym względem wygląda w Mucharzu (503 osoby) i Stryszowie (455 osób), a najgorzej w Wadowicach (3470 osób). Problem ten jest trudny do omówienia, ponieważ nieco inaczej do tej kwestii podchodzić mogą skarbnicy gmin, zastanawiając się, czy pieniądze na infrastrukturę sportową zostały dobrze zainwestowane, a inaczej zwykli mieszkańcy. Najbardziej zbliżone do siebie wskaźniki obłożenia obiektów sportowych mają gminy Kalwaria Zebrzydowska, Tomice i Brzeźnica.

Wszystko powinno być dostosowane do potrzeb społeczności lokalnej. Istotne jest zwrócenie uwagi na dostęp do infrastruktury. Należy się zastanowić nad poprawą jakości życia (w przypadku ograniczenia dostępu do infrastruktury ze względu na zbyt dużą liczbę osób przypadających na jeden obiekt nie można mówić o komforcie użytkowania) i sposobami jej osiągnięcia.

Nadto należy zwrócić uwagę na sytuację w gminach Mucharz i Stryszów w kontekście większego wykorzystania infrastruktury sportowej, gdyż mają one najniższą relację wskaźnika obłożenia obiektów sportowych do tego wskaźnika dla całego powiatu, tj. \% L/O równy odpowiednio 31\% i 28\%).

Najwyższy wskaźnik odnotowano w gminach Wadowice (216\%), Wieprz (189\%) i Spytkowice (159\%). W gminach tych należałoby rozważyć powiększenie infrastruktury sportowej.

Do znalezienia optymalnego rozwiązania problemu dotyczącego odpowiedniej liczby obiektów sportowych proponuje się wykorzystać demograficzną liczbę obiektów (tabela 2). Jest to liczba obiektów sportowych, która powinna odpowiadać liczbie ludności danej jednostki terytorialnej, tzn. jeśli gmina liczy np. $20 \%$ ludności powiatu, to powinna również posiadać ok. 20\% dostępnej infrastruktury sportowej powiatu. Demograficzna liczba obiektów jest zgodna ze strukturą demograficzną danej jednostki terytorialnej. Po odjęciu od demograficznej liczby obiektów $(\mathrm{O} 2)$ liczby obiektów faktycznie istniejących $(\mathrm{O})$ otrzymuje się parametr charakteryzujący wielkość dysproporcji pomiędzy wielkością infrastruktury sportowej a liczbą mieszkańców.

Z wyliczeń (tabela 2) wynika, że osiągnięcie demograficznej zgodności byłoby możliwe, gdyby w Stryszowie było o 11 obiektów sportowych mniej, a w Wadowicach o 11 więcej, w Mucharzu o 3 obiekty mniej, a w Wieprzu o 3 obiekty więcej, w Andrychowie o 2 obiekty mniej, a w sąsiednich gminach o 2 więcej. 
Tabela 2. Liczba mieszkańców przypadających na jeden obiekt sportowy w powiecie wadowickim (stan 31 grudnia 2014 r.)

\begin{tabular}{|c|c|c|c|c|c|c|c|c|}
\hline Gmina & $\mathrm{L}$ & $\mathrm{O}$ & $\mathrm{L} / \mathrm{O}$ & $\% \mathrm{~L}$ & $\% \mathrm{O}$ & $\mathrm{O} 2$ & $\mathrm{O} 2-\mathrm{O}$ & $\% \mathrm{~L} / \mathrm{O}$ \\
\hline \multicolumn{9}{|c|}{ Według malejącej liczby mieszkańców } \\
\hline Andrychów & 43825 & 33 & 1328 & 28 & 33 & 28 & -5 & 83 \\
\hline Wadowice & 38172 & 11 & 3470 & 24 & 11 & 24 & 13 & 216 \\
\hline Kalwaria Zebrzydowska & 19899 & 11 & 1809 & 12 & 11 & 12 & 1 & 112 \\
\hline Wieprz & 12132 & 4 & 3033 & 8 & 4 & 8 & 4 & 189 \\
\hline Spytkowice & 10212 & 4 & 2553 & 6 & 4 & 6 & 2 & 159 \\
\hline Brzeźnica & 10124 & 5 & 2025 & 6 & 5 & 6 & 1 & 126 \\
\hline Tomice & 7886 & 4 & 1972 & 5 & 4 & 5 & 1 & 123 \\
\hline Lanckorona & 6137 & 4 & 1534 & 4 & 4 & 4 & 0 & 95 \\
\hline Stryszów & 6823 & 15 & 455 & 4 & 15 & 4 & -11 & 28 \\
\hline Mucharz & 4023 & 8 & 503 & 3 & 8 & 3 & -5 & 31 \\
\hline Razem & 159233 & 99 & 1608 & 100 & 100 & 99 & 0 & 100 \\
\hline \multicolumn{9}{|c|}{ Według malejącego wskaźnika L/O } \\
\hline Wadowice & 38172 & 11 & 3470 & 24 & 11 & 24 & 13 & 216 \\
\hline Wieprz & 12132 & 4 & 3033 & 8 & 4 & 8 & 4 & 189 \\
\hline Spytkowice & 10212 & 4 & 2553 & 6 & 4 & 6 & 2 & 159 \\
\hline Brzeźnica & 10124 & 5 & 2025 & 6 & 5 & 6 & 1 & 126 \\
\hline Tomice & 7886 & 4 & 1972 & 5 & 4 & 5 & 1 & 123 \\
\hline Kalwaria Zebrzydowska & 19899 & 11 & 1809 & 12 & 11 & 12 & 1 & 112 \\
\hline Lanckorona & 6137 & 4 & 1534 & 4 & 4 & 4 & 0 & 95 \\
\hline Andrychów & 43825 & 33 & 1328 & 28 & 33 & 28 & -5 & 83 \\
\hline Mucharz & 4023 & 8 & 503 & 3 & 8 & 3 & -5 & 31 \\
\hline Stryszów & 6823 & 15 & 455 & 4 & 15 & 4 & -11 & 28 \\
\hline Razem & 159233 & 99 & 1608 & 100 & 100 & 99 & 0 & 100 \\
\hline \multicolumn{9}{|c|}{ Optymalne rozwiązanie } \\
\hline Wadowice & 38172 & 22 & 1735 & 24 & 22 & 24 & 2 & 108 \\
\hline Wieprz & 12132 & 7 & 1733 & 8 & 7 & 8 & 1 & 108 \\
\hline Spytkowice & 10212 & 6 & 1702 & 6 & 6 & 6 & 0 & 106 \\
\hline Brzeźnica & 10124 & 6 & 1687 & 6 & 6 & 6 & 0 & 105 \\
\hline Tomice & 7886 & 4 & 1972 & 5 & 4 & 5 & 1 & 123 \\
\hline Kalwaria Zebrzydowska & 19899 & 12 & 1658 & 12 & 12 & 12 & 0 & 103 \\
\hline Lanckorona & 6137 & 4 & 1534 & 4 & 4 & 4 & 0 & 95 \\
\hline Andrychów & 43825 & 29 & 1511 & 28 & 29 & 28 & -1 & 94 \\
\hline Mucharz & 4023 & 5 & 805 & 3 & 5 & 3 & -2 & 50 \\
\hline Stryszów & 6823 & 4 & 1706 & 4 & 4 & 4 & 0 & 106 \\
\hline Razem & 159233 & 99 & 1608 & 100 & 100 & 99 & 0 & 100 \\
\hline
\end{tabular}

Źródło: opracowanie własne na podstawie danych GUS. 
W konsekwencji liczba obiektów w przybliżeniu odpowiadałaby liczbie ludności zamieszkującej daną gminę, jak pokazano w trzeciej części tabeli 2.

Ważne jest zaprezentowanie, jak liczba mieszkańców powiatu przypadająca na jeden obiekt sportowy wypada na tle całego województwa małopolskiego. Według danych GUS na 31 grudnia 2014 r. Małopolskę zamieszkiwało 3368336 osób (http://demografia.stat.gov.pl/bazademografia/CustomSelectData. aspx?s=lud\&y=2014\&t=00, data dostępu: 20.08.2017). W 2014 r. Małopolska miała 2128 obiektów oraz 29 torów sportowych, których nie ma w badanym powiecie, co łącznie dało sumę 2157 obiektów. Z analizy wynika zatem, że w województwie małopolskim na jeden obiekt sportowy przypadają 1562 osoby, czyli mniej niż w powiecie wadowickim (1608 osób).

Tabela 3. Liczba mieszkańców przypadających na jeden obiekt sportowy w powiecie wadowickim w latach 2010 i 2014

\begin{tabular}{|c|c|c|c|c|c|c|c|c|}
\hline Gmina & $\mathrm{L}$ & $\mathrm{O}$ & $\mathrm{L} / \mathrm{O}$ & $\% \mathrm{~L}$ & $\% \mathrm{O}$ & $\mathrm{O} 2$ & $\mathrm{O} 2-\mathrm{O}$ & $\% \mathrm{~L} / \mathrm{O}$ \\
\hline \multicolumn{9}{|c|}{$2010 \mathrm{r}$. } \\
\hline Wadowice & 38048 & 9 & 4228 & 24 & 11 & 19 & 10 & 214 \\
\hline Kalwaria Zebrzydowska & 19690 & 5 & 3938 & 12 & 6 & 10 & 5 & 199 \\
\hline Tomice & 7640 & 3 & 2547 & 5 & 4 & 4 & 1 & 129 \\
\hline Andrychów & 43895 & 25 & 1756 & 28 & 31 & 23 & -2 & 89 \\
\hline Wieprz & 11901 & 7 & 1700 & 8 & 9 & 6 & -1 & 86 \\
\hline Spytkowice & 10100 & 6 & 1683 & 6 & 8 & 5 & -1 & 85 \\
\hline Brzeźnica & 9900 & 8 & 1238 & 6 & 10 & 5 & -3 & 63 \\
\hline Lanckorona & 6107 & 7 & 872 & 4 & 9 & 3 & -4 & 44 \\
\hline Stryszów & 6783 & 10 & 678 & 4 & 13 & 3 & -7 & 34 \\
\hline Mucharz & 3967 & 0 & & 3 & 0 & 2 & 2 & . \\
\hline Razem & 158031 & 80 & 1975 & 100 & 100 & 78 & -2 & 100 \\
\hline \multicolumn{9}{|c|}{2014 r. } \\
\hline Wadowice & 38172 & 11 & 3470 & 24 & 11 & 24 & 13 & 216 \\
\hline Wieprz & 12132 & 4 & 3033 & 8 & 4 & 8 & 4 & 189 \\
\hline Spytkowice & 10212 & 4 & 2553 & 6 & 4 & 6 & 2 & 159 \\
\hline Brzeźnica & 10124 & 5 & 2025 & 6 & 5 & 6 & 1 & 126 \\
\hline Tomice & 7886 & 4 & 1972 & 5 & 4 & 5 & 1 & 123 \\
\hline Kalwaria Zebrzydowska & 19899 & 11 & 1809 & 12 & 11 & 12 & 1 & 113 \\
\hline Lanckorona & 6137 & 4 & 1534 & 4 & 4 & 4 & 0 & 95 \\
\hline Andrychów & 43825 & 33 & 1328 & 28 & 33 & 28 & -5 & 83 \\
\hline Mucharz & 4023 & 8 & 503 & 3 & 8 & 3 & -5 & 31 \\
\hline Stryszów & 6823 & 15 & 455 & 4 & 15 & 4 & -11 & 28 \\
\hline Razem & 159233 & 99 & 1608 & 100 & 100 & 99 & 0 & 100 \\
\hline
\end{tabular}

Źródło: opracowanie własne na podstawie danych GUS. 
Rozwój infrastruktury sportowej można analizować, porównując dane dotyczące różnych czasookresów. W tym przypadku są to lata 2010 i 2014. Tabela 3 i rys. 1 prezentują dostępność obiektów sportowych dla mieszkańców powiatu wadowickiego w latach 2010 i 2014.

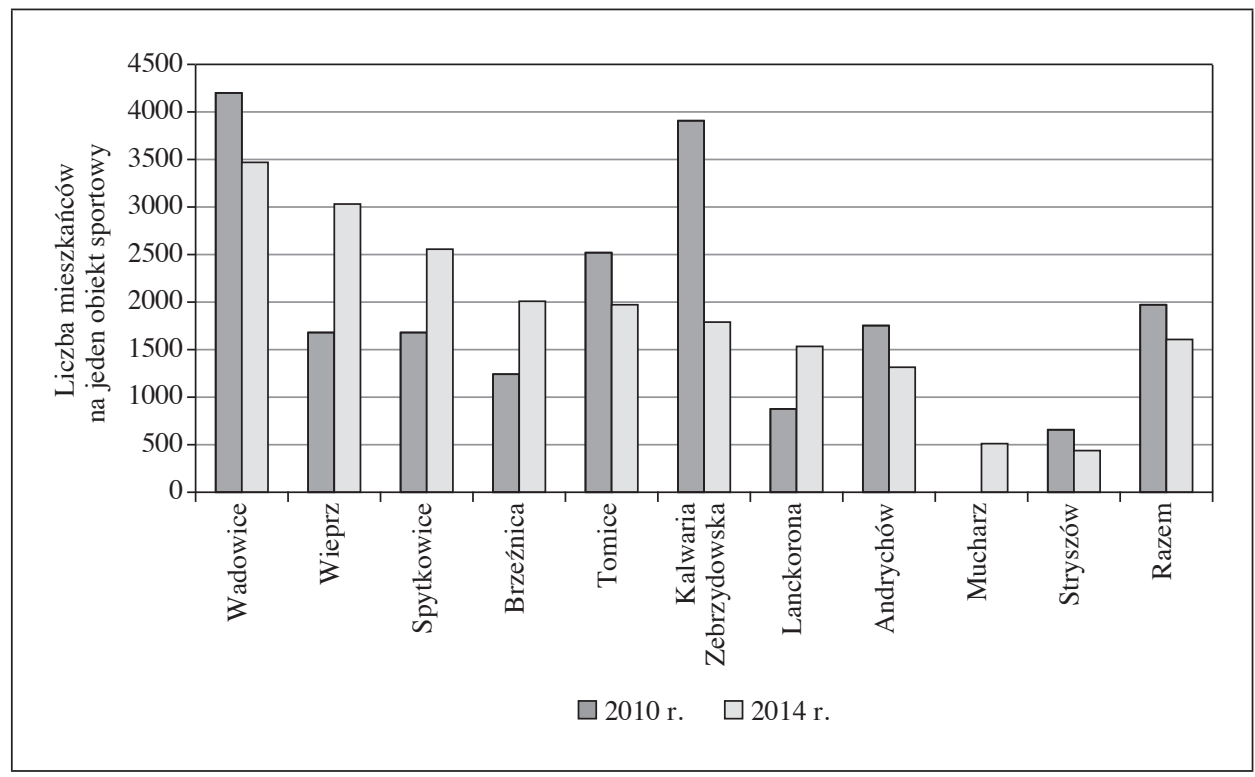

Rys. 1. Liczba mieszkańców przypadających na jeden obiekt sportowy w gminach powiatu wadowickiego w latach 2010 i 2014

Źródło: opracowanie własne na podstawie danych GUS.

W przypadku danych z 2010 r. uwagę zwracają wysokie wskaźniki L/O dla gmin Wadowice i Kalwaria Zebrzydowska, a w 2014 r. dla gmin Wadowice, Wieprz i Spytkowice. W 2014 r. można mówić o poprawie sytuacji w stosunku do 2010 r., czyli zmniejszeniu liczby osób przypadających na jeden obiekt sportowy w gminie. Analizując sytuację w poszczególnych gminach, należy zwrócić uwagę, że w Lanckoronie sytuacja się pogorszyła, gdyż zwiększyła się liczba osób przypadających na jeden obiekt sportowy. Najgorzej było w Wieprzu - w 2010 r. było to ok. 2000 osób, a w 2014 r. ok. 3000 osób. Poprawę można natomiast zaobserwować, analizując powiaty ogółem. W 2010 r. jeden obiekt sportowy przypadał na blisko 2000 osób, a w 2014 r. na nieco ponad 1600 osób. 


\section{Podsumowanie i wnioski}

Zarządzanie infrastrukturą sportową jest trudnym zadaniem. Nie wiadomo, jaki jest stan optymalny, ponieważ nie opracowano odpowiednich norm ani standardów. Gminy mogą posiadać obiekty, które pozostaną niewykorzystane. Jedno z pytań, które zadają sobie sprawujący władzę w jednostkach samorządu terytorialnego, dotyczy odpowiedniej ilości infrastruktury sportowej, a mianowicie tego, ile i jakie obiekty są gminie potrzebne. Przedstawiona analiza ma pomóc w odpowiedzi na to pytanie. Wskazuje ona także na rozbieżności w zakresie dostępności obiektów sportowych.

Gminę czy region mogą cechować specyficzne warunki, np. geograficzne, sprzyjające rozwojowi infrastruktury sportowej koniecznej do uprawiania konkretnej dyscypliny sportowej. Mogą pojawić się argumenty za budową większej liczby pewnego rodzaju obiektów lub przeciw takim inwestycjom, gdy warunki będą wykluczały ich powstanie. Stąd podjęcie decyzji inwestycyjnych musi się opierać na wielu przesłankach. Przedstawiona w artykule metoda może pomóc w podjęciu lub odrzuceniu planów inwestycyjnych w zakresie rozwoju infrastruktury sportowej.

Samorząd terytorialny jest niezwykle istotnym ogniwem w rozwoju infrastruktury sportowej. To m.in. od jego możliwości budżetowych i prowadzonej polityki zależy kształt i kierunek działań, które będą sprzyjać bądź nie odpowiedniemu rozwojowi infrastruktury i sportu. Pamiętać należy jednak o tym, że wszelkie podjęte działania powinny służyć dobru społeczeństwa, kształtowaniu dobrych postaw i poprawie jego zdrowia fizycznego i psychicznego.

\section{Literatura}

Babczuk A., Łebek P. (2013), Zakres zadań jednostek samorzqdu terytorialnego w Polsce w odniesieniu do sportu (w:) Finansowanie sportu przez samorzqd terytorialny, red. A. Babczuk, Wydawnictwo C.H. Beck, Warszawa.

Dolata M. (2010), Infrastrukturalne uwarunkowania rozwoju lokalnego, Roczniki Naukowe, t. XII, z. 1, Stowarzyszenie Ekonomistów Rolnictwa i Agrobiznesu, Warszawa.

Hadzik A., Grabara M. (2014), Inivestments in Recreational and Sports Infrastructure as a Basis for the Development of Sports Tourism on the Example of Spa Municipalities, „Polish Journal of Sport and Tourism”, vol. 21, nr 2, https://doi.org/10.2478/ pjst-2014-0010.

Konstytucja Rzeczypospolitej Polskiej z dnia 2 kwietnia 1997 r., Dz.U. nr 78, poz. 483.

Krzyżanowska K. (2005), Ocena stanu infrastruktury turystycznej i usług jej towarzyszqcych w wybranych województwach, Roczniki Naukowe, t. VII, z. 4, Stowarzyszenie Ekonomistów Rolnictwa i Agrobiznesu, Warszawa. 
Ossowska L. (2005), Poziom infrastruktury obszarów wiejskich Pomorza Środowego pomiar syntetyczny, Roczniki Naukowe, t. VII, z. 4, Stowarzyszenie Ekonomistów Rolnictwa i Agrobiznesu, Warszawa.

Physical Education and Sport at School in Europe (2013), Education, Audiovisual and Culture Executive Agency, http://eacea.ec.europa.eu/education/eurydice/documents/ thematic_reports/150EN.pdf (data dostępu: 11.11.2016).

Ratajczak M. (1999), Infrastruktura w gospodarce rynkowej, Akademia Ekonomiczna w Poznaniu, Poznań.

Rozporządzenie Rady Ministrów z dnia 24 grudnia 2007 r. w sprawie Polskiej Klasyfikacji Działalności (PKD), Dz.U. nr 251, poz. 1885.

Rzeszowski J. (2017), Finansowanie klubów sportowych z budżetu jednostek samorzqdu terytorialnego - sposoby wsparcia i studium interpretacji przepisów, „Prawo Budżetowe Państwa i Samorządu”, vol. 2, nr 5, https://doi.org/10.12775/pbps.2017.009.

Satoła Ł. (2013), Finansowanie inwestycji infrastrukturalnych $w$ jednostkach samorzqdu terytorialnego, Roczniki Naukowe, t. XV, z. 1, Stowarzyszenie Ekonomistów Rolnictwa i Agrobiznesu, Warszawa.

Sport - nawyk na całe życie (2016), Ministerstwo Sportu i Turystyki, https://d1dmfej9n5lgmh.cloudfront.net/msport/article_attachments/attachments/48152/original/ prezentacja_29_sierpnia.pdf?1378380788 (data dostępu: 11.11.2016).

Ustawa z dnia 25 czerwca 2010 r. o sporcie, Dz.U., nr 127, poz. 857.

Warunki i jakość życia dzieci w krajach rozwiniętych. Analiza porównawcza (2013), UNICEF, Florencja.

Zarzqdzanie rozwojem lokalnym - studium przypadków (1998), red. R. Broll, Wydawnictwo Akademii Ekonomicznej we Wrocławiu, Wrocław.

\section{Analysis of the Level of Sport Infrastructure on a Local and Regional Basis}

(Abstract)

The article presents a method allowing a comparative analysis of the level of sport infrastructure in a cross-section of territorial units (voivodeships of Poland, and Wadowice, the county seat). Knowing the number of sports facilities in relation to the number of inhabitants enables communities to establish a policy for developing local sports infrastructure. Due to the availability of data, the analysis was possible only for the years 2010 and 2014. The data on sports facilities were provided by the Provincial Statistical Office in Krakow. The number of inhabitants per sports facility in all territorial units was examined.

Keywords: infrastructure, sport, district, Małopolskie voivodeship, appropriate level. 